九州大学学術情報リポジトリ

Kyushu University Institutional Repository

\title{
Viability Loss and Oxidation during Desiccation of Recalcitrant Pachira macrocarpa Seeds
}

\section{Shen, Rong-Show}

Department of Horticultural Science, National Chiayi University

Lu, Shao-Wei

Department of Horticultural Science, National Chiayi University

Huang, Kuang-Liang

Department of Horticultural Science, National Chiayi University

Chang, Yu-Sen

Department of Horticulture and Landscape Architecture, National Taiwan University

他

https://doi.org/10.5109/1526292

出版情報：九州大学大学院農学研究院紀要. 60 (1)，pp.23-32，2015-02-27. Faculty of Agriculture， Kyushu University

バージョン :

権利関係 : 


\title{
Viability Loss and Oxidation during Desiccation of Recalcitrant Pachira macrocarpa Seeds
}

\author{
Rong-Show SHEN ${ }^{1 *}$, Shao-Wei LU ${ }^{1}$, Kuang-Liang HUANG ${ }^{1}$, \\ Yu-Sen CHANG ${ }^{2}$ and Ikuo MIYAJIMA ${ }^{3}$ \\ Institute of Tropical Agriculture, Faculty of Agriculture, Kyushu University, \\ Fukuoka 812-8581, Japan \\ (Received October 20, 2014 and accepted November 14, 2014)
}

\begin{abstract}
This study investigated the correlation between the moisture content and viability of Pachira macrocarpa seeds, and observed the changes in seed oxidation and oxidation resistance during the desiccation process. The average moisture content of a fresh mature $P$. macrocarpa seed was approximately $1.93 \mathrm{gH}_{2} \mathrm{O}^{-\mathrm{g}^{-1}}$ DW. When the seeds were placed into desiccating environments at $25^{\circ} \mathrm{C}$ with $60 \%$ relative humidity, seed viability and moisture content exhibited highly curve correlation. The $\mathrm{R}^{2}$ reached 0.98 , and seed viability rapidly declined as the moisture content decreased. This test was observed causing seed death occurred at a critical moisture content of $1.4 \mathrm{gH}_{2} \mathrm{O} \cdot \mathrm{g}^{-1} \mathrm{DW}$, where the seed germination percentage was $0 \%$. This indicates that $P$. macrocarpa seeds are not only recalcitrant but also sensitive to desiccation. Furthermore, the seed oxidation resistance showed that after 0-5 days of desiccation, the superoxide anion radical $\left(\mathrm{O}_{2}^{-}\right)$and hydrogen peroxide $\left(\mathrm{H}_{2} \mathrm{O}_{2}\right)$ levels increased as the seed moisture content decreased. The activity of the antioxidant enzyme superoxidase dismutase (SOD) and ascorbate peroxidase (APX) also decreased with the seed moisture content. When the seeds were desiccated to a moisture content of $1.22 \mathrm{gH}_{2} \mathrm{O} \cdot \mathrm{g}^{-1} \mathrm{DW}$, the SOD activity was reduced to half that of a fresh seed. Although the ascorbate-glutathione cycle continued to function, the seed's malondialdehyde (MDA) content increased 1.5 times, which expedited seed oxidation. However, the reduction of $P$. macrocarpa seed viability during desiccation occurred before significant oxidation, while seed death may have been caused by physical damage not metabolic injury.
\end{abstract}

Key words: antioxidant enzyme, ascorbate peroxidase, malondialdehyde, superoxidase dismutase

\section{INTRODUCTION}

Seedlings production of braiding types in malabar chestnut [P. macrocarpa (Cham. \& Schl.) Schl.] is the most important export potted foliage in Taiwan, while the seeds are commonly considered recalcitrant or shortlived. When Li et al. (2009) desiccated P. macrocarpa seeds with silica gel, seed viability decreased with increased desiccation time. However, no reports or clear definitions exist regarding the correlation between the seed viability and moisture content for $P$. macrocarpa seeds, or for the critical moisture content at seed death. Currently, $P$. macrocarpa seeds can only be stored for approximately one month (Sun et al., 2011). Therefore, to overcome the limited factor of $P$. macrocarpa seed storage life, an in-depth understanding of the physiological reaction to desiccation is required to benefit the development of storage technology.

Roberts (1973) established a seed viability equation based on their sensitivity to desiccation, classifying seeds into orthodox and recalcitrant seeds. Subsequent reports have categorized seeds into various desiccation tolerance types based on their sensitivity to desiccation and tem-

\footnotetext{
Department of Horticultural Science, National Chiayi University, Chiayi 60004, Taiwan, ROC.

2 Department of Horticulture and Landscape Architecture, National Taiwan University, Taipei 10617, Taiwan, ROC.

Institute of Tropical Agriculture, Faculty of Agriculture, Kyushu University, Fukuoka 812-8581, Japan

* Corresponding author (E-mail address: garden@mail.ncyu. edu.tw, telephone: +88652717431 , fax: +88652775472.)
}

perature (Farrant et al., 1988; Ellis et al., 1991; Hong and Ellis, 1996), and even attributed the characteristics of seed longevity to quantitative trait (Berjak and Pammenter, 2001; Win, 2008). Hong et al. (1996, 1998) also categorized seeds into orthodox, recalcitrant, and intermediate seeds based on their reaction to desiccation, which is currently the most widely accepted categorization method. However, no effective methods exist to preserve recalcitrant seeds for long terms. The most obvious characteristic of recalcitrant seeds is their sensitivity to desiccation. In addition, regarding the desiccation of Camellia sinensis Luntze (Chen et al., 2010), Telfairia occidental Hook. f. (Ajayi et al., 2006), Lasia spinosa (L.) Thwait. (Tang and Long, 2008), Quercus robur L. (Bonner, 1996), and Artocarpus heterophyllus Lamk. (Wesley-Smith et al., 2001) recalcitrant seeds, the germination percentages all declined as the desiccation time increased or the moisture content decreased. When desiccated to a seed moisture content of $20 \%$ to $30 \%$, the majority of the seeds exhibited no germination vigor. This indicates that most recalcitrant seeds cannot tolerate seed moistures below 20\%, and seed moisture content is a key factor that affects the viability of recalcitrant seeds.

Furthermore, some plant species have a specific threshold of seed moisture content on storage longevity. Once the moisture content declines below this threshold, the seed no longer possesses germination vigor. Exploring the reason, some reports have indicated that the death of recalcitrant seeds may be caused by an increase in reactive oxygen species (ROS) after desiccation, and the 
lack of an anti-oxidation system. For example, following with a reduced seed moisture content, Acer saccharinum L. (Pukacka and Ratajczak, 2006), C. sinensis Luntze (Chen et al., 2010), Antiaris toxicaria L. (Xin et al., 2010), and Araucaria bidwillii Hook (Francini et al., 2006) seeds showed an increase in $\mathrm{O}_{2}^{-}, \mathrm{H}_{2} \mathrm{O}_{2}$, free radicals, and other reactive oxygen species. Plants typically possess an anti-oxidation system to eliminate free radicals; however, anti-oxidation enzymes and other antioxidants all decline after recalcitrant seeds are desiccated. Resembling the reaction after desiccation, the SOD activity of $P$. macrocarpa and Theobroma cacao seeds decreased with the seed moisture content (Li and Sun, 1999); after SOD reduces $\mathrm{O}_{2}^{--}$into $\mathrm{H}_{2} \mathrm{O}_{2}$, ascorbate peroxidase (APX) reduces $\mathrm{H}_{2} \mathrm{O}_{2}$ into $\mathrm{H}_{2} \mathrm{O}$. While, the APX activity in both $A$. toxicaria and T. cacao recalcitrant seeds decreased with the seed moisture content (Li and Sun, 1999; Xin et al., 2010).

For antioxidant level change, the glutathione (GSH) in $Q$. robur and sugar maple seeds were reduced as the seed moisture content declined (Kranner et al., 2006; Pukacka and Ratajczak, 2006). After sugar maple seeds were desiccated, the GSH and glutathione disulphide (GSSG) ratio declined, and the seeds exhibited oxidation (Pukacka and Ratajczak, 2006). To seem like this, after Castanea sativa seeds were dried, the $\mathrm{E}_{\mathrm{GSSG} / 2 \mathrm{GSH}}$ value gradually became positive, indicating that the seed oxidation condition had deteriorated (Roach et al., 2010). If seeds cannot eliminate the reactive oxygen species produced during desiccation, lipid peroxidation may occur. During the desiccation of $A$. toxicaria and T. cacao and $A$. bidwillii seeds, the quantity of the lipid peroxidation indicator, that is, thiobarbituric acid reactive substances (TBARS), increased as the seed moisture content decreased (Cheng and Song, 2008; Francini et al., 2006; $\mathrm{Li}$ and Sun, 1999), then caused cell membranes to rupture and increasing the ion leakage rate (Kioko et al., 2006; Xin et al., 2010). Thus, during the desiccation process, the anti-oxidation system of recalcitrant seeds becomes imbalanced and oxidation occurs in the seed interior, leading to seed death. However, although A. toxicaria seed exhibited oxidation, the level of oxidation was insufficient to cause seed death. Thus, seed death may result from severe mechanical damage to the cells during desiccation (Xin et al., 2010), not metabolic injury.

Therefore, this study investigated the correlation between the moisture content and viability of $P$. macrocarpa seeds, and exploring the seed desiccation tolerance to provide relevant physiology information for future storage of $P$. macrocarpa seeds. We also examined the moisture content of $P$. macrocarpa seeds and its effect on oxidation resistance. The results were adopted to explore the reactive oxygen species, anti-oxidation system, and oxidation situation in recalcitrant P. macrocarpa seeds following desiccation, and to understand the physiological aspects for the lack of desiccation tolerance in recalcitrant seeds.

\section{MATERIALS AND METHODS}

\section{Seed materials}

Mature P. macrocarpa fruits were harvested and transported to the laboratory within 1 day, and then placed in shade until they split naturally. After splitting, seeds were extracted and screened based on a visual inspection of their exterior plumpness. All mature seeds with a fresh weight of over $2.5 \mathrm{~g}$ were selected for testing.

\section{Desiccation and germination test}

The seeds were placed indoors for desiccation at a temperature of $25 \pm 1^{\circ} \mathrm{C}$ and a relative humidity of $60 \%$ for 0 to 12 days. Each treatment was repeated three times using 15 seeds for each replication. The test period was from March 2, 2012, to March 14, 2012.

After 0 to 12 days of indoor desiccation, we selected five seeds from each treatment and followed WesleySmith (2001) analysis method for testing. The seeds were dried at $80^{\circ} \mathrm{C}$ in a hot air oven for $36 \mathrm{~h}$ until a constant weight was achieved. The formula for calculating the seed moisture content following desiccation was [(postindoor desiccation weight - dry weight)/dry weight] $\times$ $100 \%$. We then selected 10 seeds from each treatment, the seed coat removed, and sowed the seeds in a plug tray with 35 plugs and plug hole diameter of $7 \mathrm{~cm}$. The plugs were filled with peat-moss (Klasmann-Deilmann Co., Ltd., Germany) as the sowing medium, and the trays were placed in greenhouse provided a day/night temperature of $30 / 25^{\circ} \mathrm{C}$ at Department of Horticultural Science of National Chiayi University to investigate seed viability. Seed viability is represented by the germination percentage and seedling rate after sowing. The calculation formula is germination percentage $=$ (number of germinations/number of seeds sown) $\times 100 \%$ and seedling rate $=($ number of seedlings/number of seeds sown $) \times 100 \%$.

\section{Microscopy}

During this experiment, we also conducted a biopsy of hypocotyl tissues obtained from seeds desiccated for 9 days, and seeds that had not undergone desiccation for control group. The biopsy technique was referencing the paraffin section processing methods by Tsai (1975), fixation, dehydration, infiltration, and embedding/casting were sequentially employed, and a microtome was used to sectioning. The fixation liquid was a solution of $37 \%$ formaldehyde, acetic acid, and 50\% alcohol in a volume ratio of 5:5:90. Hypocotyl tissue was placed in a $6 \mathrm{~mL}$ sample vial for fixation. Tissue coverage by the fixation solution was set as the standard, which involved at least $3 \mathrm{~mL}$ of the solution or more. Vacuum suction (15 m per h) was applied in conjunction, and the fixation process conducted for a total of $72 \mathrm{~h}$. After extracting the fixation solution, alcohol was mixed with tertiary butyl alcohol (TBA) into a dehydration solution to conduct dehydration. Finally, the tissue sample was placed in 100\% TBA for paraffin infiltration. For the paraffin infiltration process, a small amount of pure paraffin was employed to replace TBA. This was conducted in a $60^{\circ} \mathrm{C}$ oven until the TBA had completely evaporated. Paper embedding 
cassettes were used to conduct paraffin embedding on the paraffin infiltrated tissue. After cooling and solidifying, the paraffin block was trimmed with a razor. A manual rotary microtome (Nanolytik ${ }^{\circledR} 4060$, Germany) was employed to cut $10 \mu \mathrm{m}$ sections. The sectioned continuous paraffin ribbon was placed on a glass slide coated with adhesive and formalin dilution, and the transferred to a $38^{\circ} \mathrm{C}$ paraffin section mounting bath (Sakura SV-C2, Japan) for mounting. Dyeing was performed after two days of mounting. During the dying process, xylene substitute (Thermo Scientific Inc., U.S.A.) was used to melt the paraffin. After a series of alcohol immersions and dying with safranin, the sample underwent a series of immersions in alcohol as well as xylene substitute, thereby completing the procedure. A dyed glass slide was employed with an optical microscope (Zeiss Axio Imager. A1, Carl Zeiss AG, Germany) and lighting equipment (Canon A620, Canon Inc., Japan) to make observations.

\section{Biochemical assays}

This experiment employed the same seed material as used for desiccation. The material was placed in the environment described above to desiccate for up to 5 days. After desiccation, five seeds were selected from each treatment. A freeze dryer (Ilshin Lab. Co., Ltd., Korea) was used to freeze dry and grind the seeds for the oxidation resistance experiment. The experimentation period was from March 2, 2012, to March 7, 2012.

The analysis results of the seeds' peroxide level, anti-oxidation enzyme activity, antioxidant quantity, and oxidation following desiccation are explained below.

\section{Reactive Oxygen species (ROS) measurement}

\section{(1). Hydrogen peroxide $\left(\mathrm{H}_{2} \mathrm{O}_{2}\right)$}

Referencing the method used by Sagisaka (1976), we obtained $0.4 \mathrm{~g}$ of freeze-dried $P$. macrocarpa seeds and added $4 \mathrm{~mL}$ of $5 \%$ trichloroacetic acid (TCA) as the extraction liquid for ground extraction in a cold bath. After the mixture was centrifuged at $18,000 \times \mathrm{g}$ and $4^{\circ} \mathrm{C}$ for $30 \mathrm{~min}, 10 \mu \mathrm{L}$ of the extracted solution was combined with $260 \mu \mathrm{L}$ of the reacting liquid [containing $10 \mathrm{mM}$ of ferrous ammonium sulfate, $2.5 \mathrm{mM}$ of potassium thiocyanide, and 50\% (w/v) TCA] and mixed thoroughly. The solution's absorbency change per unit time at a 480-nm wavelength was measured, and $\mathrm{H} 2 \mathrm{O} 2$ was used as the standard to estimate $\mathrm{H}_{2} \mathrm{O}_{2}$ quantity.

(2). Superoxide anion $\left(\mathrm{O}_{2}^{-}\right)$

Referencing the method used by Liu et al. (2012), we obtained $1 \mathrm{~g}$ of freeze dried $P$. macrocarpa seed powder, which we combined with $1 \mathrm{~mL}$ of potassium phosphate buffer solution ( $20 \mathrm{mM}, \mathrm{pH} 6.0$ ) containing $500 \mu \mathrm{M}$ XTT of sodium salt (XTT). This mixture was placed in a $25^{\circ} \mathrm{C}$ darkroom for $3 \mathrm{~h}$ of oscillating reaction, and then tested for absorptivity changes in $470 \mathrm{~nm}$.

\section{Anti-oxidation enzyme activity analysis}

(1). Ascorbate peroxidase (APX)

Based on the method used by Nakano and Asada (1981), we obtained $0.4 \mathrm{~g}$ of freeze dried P. macrocarpa seed, added $4 \mathrm{~mL}$ of sodium phosphate buffer $(50 \mathrm{mM}$,
$\mathrm{pH}$ 6.8) solution, and then ground and extracted it in an ice bath. The mixture was centrifuged at $12,000 \mathrm{~g}$ and $4^{\circ} \mathrm{C}$ for $20 \mathrm{~min}$. Then $0.2 \mathrm{~mL}$ of the extracted fluid was combined with $2.9 \mathrm{~mL}$ of the reacting liquid (containing $1 \mathrm{~mL}$ of $100 \mathrm{mM} \mathrm{pH} 7.0$ potassium phosphate buffer, $1 \mathrm{~mL} 1.5 \mathrm{mM}$ of ascorbate, $0.4 \mathrm{~mL} 0.75$ of mM EDTA, and $0.5 \mathrm{~mL} 6 \mathrm{mM}$ of $\mathrm{H}_{2} \mathrm{O}_{2}$ ) and mixed evenly. A wavelength of $290 \mathrm{~nm}$ was used to test the changes in absorptivity. A photoelectric colorimeter absorption coefficient of $2.8 \mathrm{mM}^{-1} \cdot \mathrm{cm}^{-1}$ was used to estimate the AsA quantity. The enzyme activity was defined as the change in AsA consumption per unit time.

(2). Superoxide dismutase (SOD)

Based on the method used by Paoletti et al. (1986), we obtained $0.4 \mathrm{~g}$ of freeze dried $P$. macrocarpa seed, added $2 \mathrm{~mL}$ of sodium phosphate buffer (50 mM, pH 7.4) solution, and then ground and extracted it in an ice bath. The mixture was centrifuged at $15,000 \mathrm{~g}$ and $4^{\circ} \mathrm{C}$ for $30 \mathrm{~min}$. Subsequently, $0.1 \mathrm{~mL}$ of the extracted liquid was combined with $2.73 \mathrm{~mL}$ of the reacting liquid [containing $1.6 \mathrm{~mL}$ of $100 \mathrm{mM} \mathrm{pH} 7.4$ triethanol amine diethanolamine (Tea-Dea), $80 \mu \mathrm{L}$ of $7.5 \mathrm{mM}$ reduced-form nicotin-amide adenine dinucleotide (NADH), $50 \mu \mathrm{L}$ of $100 \mathrm{mM} \mathrm{pH} 7.0$ EDTA/ $\mathrm{MnCl}_{2}$, and $1 \mathrm{~mL}$ of $10 \mathrm{mM} \mathrm{2-mercaptoethanol)]}$ and mixed evenly. A wavelength of $340 \mathrm{~nm}$ was employed to test the changes in absorptivity, using a molar absorption coefficient of $6.22 \mathrm{mM}^{-1} \cdot \mathrm{cm}^{-1}$ for estimation. The enzyme activity was measured according to the enzyme activity per gram of fresh weight. The enzyme activity is indicated by the unit activity per gram of fresh weight, and each unit activity was defined as the quantity required for SOD to inhibit the NADH oxidation rate by $50 \%$.

\section{Antioxidant quantity analysis}

(1). Glutathione (GSH)

After obtaining $0.4 \mathrm{~g}$ of freeze dried $P$. macrocarpa seed, $4 \mathrm{~mL}$ of sulfosalicylic acid (5\%, w/v) solution was added, and the mixture ground and extracted in an ice bath. The mixture was centrifuged at $15,000 \times \mathrm{g}$ and $4^{\circ} \mathrm{C}$ for $10 \mathrm{~min}$, according the methods of Smith (1985). The samples obtained $0.25 \mathrm{~mL}$ of the extracted sample liquid and then added $0.15 \mathrm{~mL}$ of $0.1 \mathrm{M}$ potassium phosphate buffer (pH 7.5). Following oscillation mixing, $1.4 \mathrm{~mL}$ of the reacting liquid [containing $1 \mathrm{~mL}$ of $0.1 \mathrm{M}$ sodium phosphate buffer ( $\mathrm{pH} 7.5$, with $5 \mathrm{mM}$ of ethylenediaminetetra-acetic acid (EDTA))] and $0.4 \mathrm{~mL}$ of $6 \mathrm{mM}$ dithionitro-benzoic acid (DTNB) were added. After reacting for $10 \mathrm{~min}$ at $30^{\circ} \mathrm{C}, 0.2 \mathrm{~mL}$ of $2 \mathrm{mM} \mathrm{NADPH}$ and $0.2 \mathrm{~mL}$ of glutathione reductase ( 2.5 unit. $\mathrm{mL}^{-1}$ ) were added, and the solution was evenly mixed. A wavelength of $412 \mathrm{~nm}$ was used to test the changes in absorptivity. GSH was used as the standard to estimate GSH quantity. The $0.1 \mathrm{~mL}$ of the extracted sample fluid into which $0.15 \mathrm{~mL}$ of $0.1 \mathrm{M}$ potassium phosphate buffer ( $\mathrm{pH} 7.5$ ) was mixed before adding $40 \mu \mathrm{L}$ of 2 -vinylpridine to prevent the GSH from oxidizing into glutathione disulfide (GSSG). After mixing, $60 \mu \mathrm{L}$ of triethanolamine $(35 \mathrm{mM})$ was added along the tube wall before oscillation mixing. The solution was left at room temperature to react for at least $1 \mathrm{~h}$ to eliminate the GSH in the sample. Then $1.5 \mathrm{~mL}$ of the 
reacting fluid (containing $0.1 \mathrm{M}$ of sodium phosphate buffer $\mathrm{pH} 7.5$ and $5 \mathrm{mM}$ of EDTA) and $0.4 \mathrm{~mL}$ of $6 \mathrm{mM}$ dithionitro-benzoic acid (DTNB) were added. After reacting for $10 \mathrm{~min}$ at $30^{\circ} \mathrm{C}, 0.2 \mathrm{~mL}$ of $2 \mathrm{mM} \mathrm{NADPH}$ and $0.2 \mathrm{~mL}$ of glutathione reductase $\left(5\right.$ unit. $\left.\mathrm{mL}^{-1}\right)$ were mixed into the solution. A wavelength of $412 \mathrm{~nm}$ was used to test the changes in absorptivity, and glutathione disulfide (GSSG) was set as the standard for estimating the quantity of GSSG.

(2). Ascorbate (AsA)

The AsA quantity was based on the method employed by Law et al. (1983), using $0.4 \mathrm{~g}$ of freeze dried P. macrocarpa seed. The samples were added $4 \mathrm{~mL}$ of $0.1 \mathrm{M}$ pH 6.8 potassium phosphate buffer solution and then ground and extracted the mixture in an ice bath. After centrifugation at $15,000 \times \mathrm{g}$ and $4^{\circ} \mathrm{C}$ for $30 \mathrm{~min}$, the supernatant became the enzyme extraction liquid. We mixed $100 \mu \mathrm{L}$ of the extracted sample liquid with $150 \mathrm{mM}$ of $\mathrm{pH}$ 7.4 sodium phosphate buffer, added $50 \mu \mathrm{L}$ of $10 \mathrm{mM}$ DL-dithiothreitol (DTT), and then left the solution at room temperature for $15 \mathrm{~min}$. Subsequently, $50 \mu \mathrm{L}$ of 0.5\% N-ethylmaleimide was added and mixture shaken until evenly mixed. After adding $200 \mu \mathrm{L}$ of $10 \%$ TCA and $200 \mu \mathrm{L}$ of $44 \%$ (v/v) $\mathrm{H}_{3} \mathrm{PO}_{4}$, the mixture was again shaken until mixed. Next, $200 \mu \mathrm{L}$ of $4 \%$ (w/v) bipyridyl (dissolved in $90 \%$ ethanol) was mixed into the solution. Finally, $100 \mu \mathrm{L}$ of $3 \%(\mathrm{w} / \mathrm{v}) \mathrm{FeCl}_{3}$ was added, and the solution placed in an oscillator at $37^{\circ} \mathrm{C}$ to react for $1 \mathrm{~h}$. A wavelength of $525 \mathrm{~nm}$ was used to test the changes in absorptivity. The AsA solution was used as the standard to estimate the total AsA quantity. Besides not adding DTT and N-ethylmaleimide to prevent the dehydroascorbate (DHAsA) from reducing to AsA, the procedures for the AsA quantity test were identical to those followed for the total ascorbate analysis.

\section{Determination of lipid peroxidation}

Referencing the method used by Heath and Packer (1968), $0.4 \mathrm{~g}$ of freeze dried P. macrocarpa seed was ground and extracted with $4 \mathrm{~mL}$ of $5 \%$ TCA extraction liquid in a cold bath. After centrifugation at 18,000 g and $4^{\circ} \mathrm{C}$ for $30 \mathrm{~min}, 1 \mathrm{~mL}$ of $P$. macrocarpa extraction liquid was added to $4 \mathrm{~mL}$ of the reacting liquid [0.5\% (w/v) thiobarbituric acid (TBA) containing 20\% (w/v) TCA]. After this solution was left in a $95^{\circ} \mathrm{C}$ bath for $30 \mathrm{~min}$, it was quickly placed in ice for cooling and to stop the reaction. After the solution cooled, it was centrifuged at 3,000 g for $10 \mathrm{~min}$. Wavelengths of $532 \mathrm{~nm}$ and $600 \mathrm{~nm}$ were used to test the changes in absorptivity. A molar absorption coefficient of $155 \mathrm{mM}^{-1} \cdot \mathrm{cm}$ was used to estimate malondialdehyde (MDA) quantity.

\section{Statistical analysis}

The experiments adopted a completely randomized design (CRD). The experiment results were analyzed with CoStat 6.4 statistical software (CoHort Software, Monterey, CA, U.S.A.). Analysis of variance (ANOVA) was performed to assess the significances, and the least significant difference (LSD) test was conducted to identify whether significant variances $(p \leqq .05)$ in the test procedures existed. Experiment data in percentages were converted using a Bliss conversion table prior to statistical analysis. SigmaPlot ${ }^{\circledR} 10.0$ statistical software package (Systat software Inc. USA) was used for plotting and comparing the experiment results.

\section{RESULTS}

The experiment results showed that the average moisture content of fresh $P$. macrocarpa seeds was approximately $1.93 \mathrm{gH}_{2} \mathrm{O} \cdot \mathrm{g}^{-1} \mathrm{DW}$ (Fig. 1A). After sowing, the germination percentage reached $100 \%$. When the seeds were desiccated at an indoor temperature of $25^{\circ} \mathrm{C}$ and a relative humidity of $60 \%$, the seed moisture content decreased with increases in desiccation time. This decrease in moisture content and increased desiccation time exhibited a high linear correlation $\left(R^{2}=0.95\right)$. After 12 day of slow desiccation, the seed moisture content was $1.07 \mathrm{gH}_{2} \mathrm{O} \cdot \mathrm{g}^{-1} \mathrm{DW}$ (Fig. 1A). The germination percentage and seedling rate rapidly declined with decreases in the seed moisture content. Simultaneously, the germination percentage and seedling rate exhibited a curve highly correlated with seed moisture content (Fig. 1B). When the coefficient of determination $\left(\mathrm{R}^{2}\right)$ for the seed moisture content and germination/seedling rate were 0.98 and 0.97 , the mathematical equations were $\mathrm{y}=131 \mathrm{x}^{2}-284.0 \mathrm{x}$ +148.7 and $y=221.7 x^{2}-485.3 x+258.5$, respectively. In addition, when the germination percentage declined to
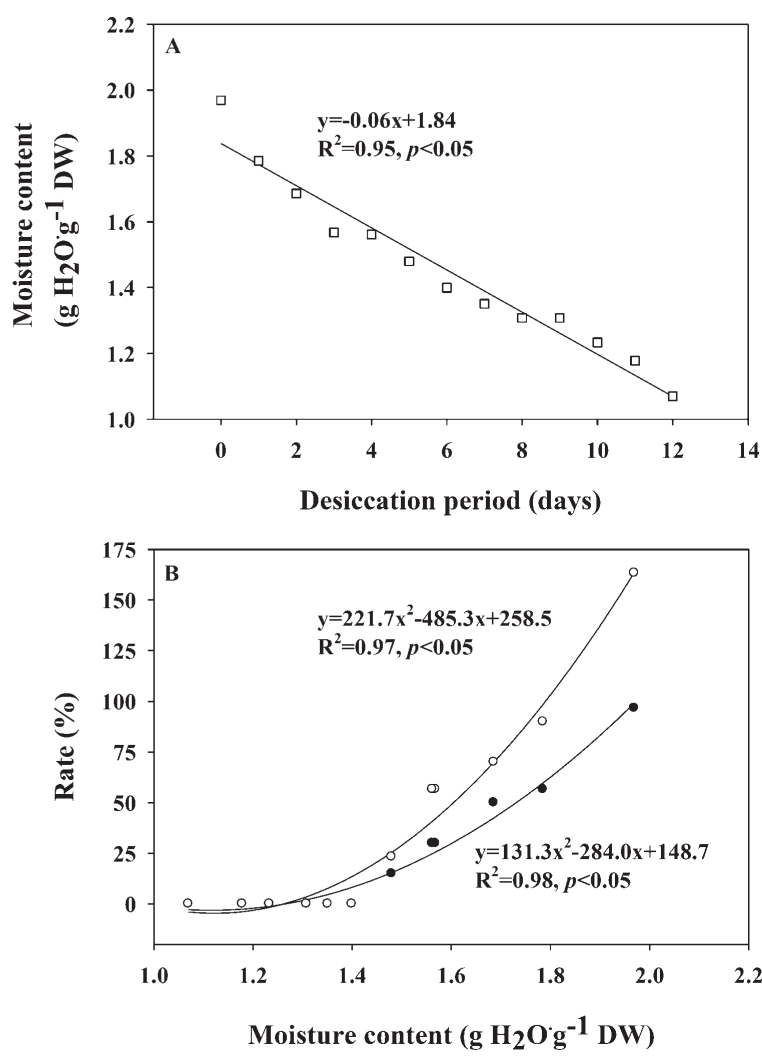

Fig. 1. Correlation between moisture content of Pachira macrocarpa seeds and drying time at $25^{\circ} \mathrm{C}$ and $\mathrm{RH} 60 \%$ (A) and effect of moisture content on germination rate and seedling rate $(\bigcirc)$ of Pachira macrocarpa seeds (B). 
$50 \%$, the seed moisture content was approximately $1.7 \mathrm{gH}_{2} \mathrm{O} \cdot \mathrm{g}^{-1} \mathrm{DW}$. After desiccating for 7 days, when the moisture content had declined to $1.4 \mathrm{gH}_{2} \mathrm{O} \cdot \mathrm{g}^{-1} \mathrm{DW}$, the seeds no longer possessed germination abilities (Fig. 1B). The hypocotyl biopsy of $P$. macrocarpa seeds that were not desiccated showed that the cells were organized into neat lines, the cell membrane structure was complete, and clear divisions between cells was evident. After dying with safranin, clear cell nuclear structures were observed, and the cell nuclear membrane maintained completeness. A clear division between the cell nucleus and cytoplasm was also noted (Fig. 2A). While, a hypocotyl biopsy of seeds desiccated for 9 days was performed to observe the cell structure; the results showed unclear divisions between cells. Thereby, the cell membrane structures appeared ruptured, and the division between the cell nucleus and the cytoplasm was unclear. This suggested that the nuclear membrane of the cells had ruptured (Fig. 2B).

Observing the changes in reactive oxygen species after $P$. macrocarpa seeds were desiccated for up to 5 days, superoxide anion radical $\left(\mathrm{O}_{2}^{-}\right)$and hydrogen peroxide $\left(\mathrm{H}_{2} \mathrm{O}_{2}\right)$ increased as the seed moisture content decreased. The $\mathrm{O}_{2}^{-}$and $\mathrm{H}_{2} \mathrm{O}_{2}$ content of the seeds that

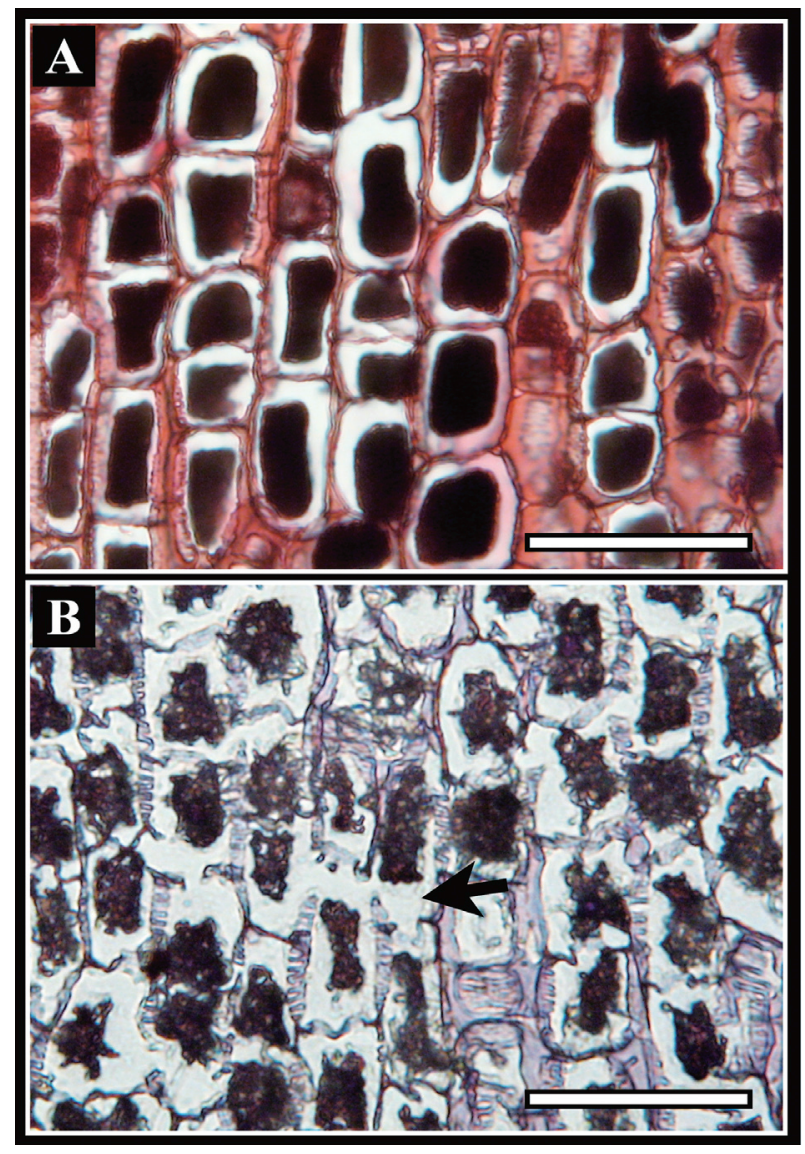

Fig. 2. Transverse sections of embryonal axis tissue after 0 day (A) and 9 days (B) desiccation of Pachira macrocarpa. The cells arranged in neat rows, and the cell membrane and nucleus appeared distinct (A) ; After 9-day desiccation to moisture content at $1.2 \mathrm{gH} \mathrm{H}_{2} \cdot \mathrm{g}^{-1} \mathrm{DW}$, cells lose typified cells rank (B), and visible destroyed cell membrane and abnormally shaped nucleus indicated intercellular confusion (arrow-head). were not desiccated was 0.25 and $107.5 \mu \mathrm{g} \cdot \mathrm{g}^{-1} \mathrm{DW}$, respectively. For seeds desiccated to a moisture content of $1.47 \mathrm{gH}_{2} \mathrm{O} \cdot \mathrm{g}^{-1} \mathrm{DW}$, the seed $\mathrm{O}_{2}^{-}$content was significantly higher than that of the seeds that were not desiccated. When the moisture content declined to $1.22 \mathrm{gH}_{2} \mathrm{O} \cdot \mathrm{g}^{-1} \mathrm{DW}$, the $\mathrm{O}_{2}^{--}$content reached a peak of $0.38 \mu \mathrm{g} \cdot \mathrm{g}^{-1}$ DW. When the seed moisture content declined to $1.87 \mathrm{gH}_{2} \mathrm{O} \cdot \mathrm{g}^{-1} \mathrm{DW}$, the $\mathrm{H}_{2} \mathrm{O}_{2}$ content of desiccated seeds was significantly higher than the $1.89 \mathrm{gH}_{2} \mathrm{O} \cdot \mathrm{g}^{-1} \mathrm{DW}$ of seeds that were not desiccated. In addition, when the seeds were desiccated to a moisture content of $1.08 \mathrm{gH}_{2} \mathrm{O} \cdot \mathrm{g}^{-1} \mathrm{DW}$, we can observe that $\mathrm{H}_{2} \mathrm{O}_{2}$ quantity increased to $162.3 \mu \mathrm{g} \cdot \mathrm{g}^{-1} \mathrm{DW}$ (Fig. 3).

After desiccation, we also observed changes in the anti-oxidation enzyme activity. The SOD activity of seeds that were not desiccated was 3.62 units. $^{-1}$ DW. With decreases in seed moisture content, SOD activity showed a decreasing trend. When the seed moisture content declined to $1.72 \mathrm{gH}_{2} \mathrm{O} \cdot \mathrm{g}^{-1} \mathrm{DW}$, the SOD activity of desiccated seeds was significantly lower than that of the seeds that were not desiccated. When the seeds were desiccated to a moisture content of $1.22 \mathrm{gH}_{2} \mathrm{O} \cdot \mathrm{g}^{-1} \mathrm{DW}$, SOD activity was reduced to approximately 2.43 units. $\mathrm{g}^{-1} \mathrm{DW}$, half that of seeds that were not desiccated (Fig. 4A). The APX activity in seeds that were not desiccated was approximately $28.95 \mu \mathrm{mol} \cdot \mathrm{g}^{-1} \mathrm{DW} \cdot \mathrm{min}^{-1}$ and showed an increasing trend until the seeds were desiccated to $1.72 \mathrm{gH}_{2} \mathrm{O} \cdot \mathrm{g}^{-1} \mathrm{DW}$. Further desiccation reduced the activity. When the seed moisture content was $1.22 \mathrm{gH}_{2} \mathrm{O} \cdot \mathrm{g}^{-1}$ DW, the APX activity was approximately $18.94 \mu \mathrm{mol} \cdot \mathrm{g}^{-1}$ DW. min $^{-1}$, significantly lower than that of the seeds that were not desiccated (Fig. 4B).

In addition, the total quantity of the antioxidant ascorbic acid showed an increase during the early stages of desiccation, and when the moisture content was $1.87 \mathrm{gH}_{2} \mathrm{O} \cdot \mathrm{g}^{-1} \mathrm{DW}$, the total ascorbic acid quantity was significantly higher than that during other processes. However, after this peak, the quantity declined as the moisture content decreased. The AsA quantity showed no significant change during the desiccation process. The

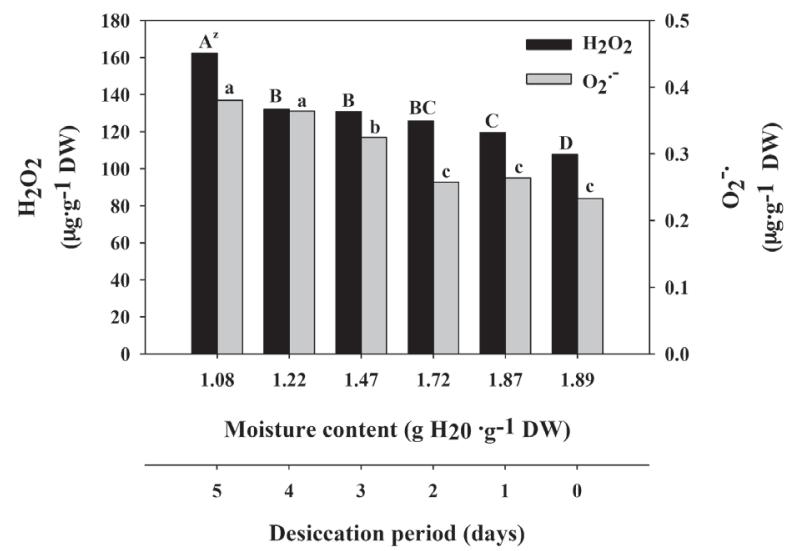

Fig. 3. Effect of seed moisture content on superoxide anion $\left(\mathrm{O}_{2}^{-}\right)$ and hydrogen peroxide $\left(\mathrm{H}_{2} \mathrm{O}_{2}\right)$ content in Pachira macrocarpa.

${ }^{z}$ Means followed by the same letter within each column are not significantly different at the 5\% level by LSD test 


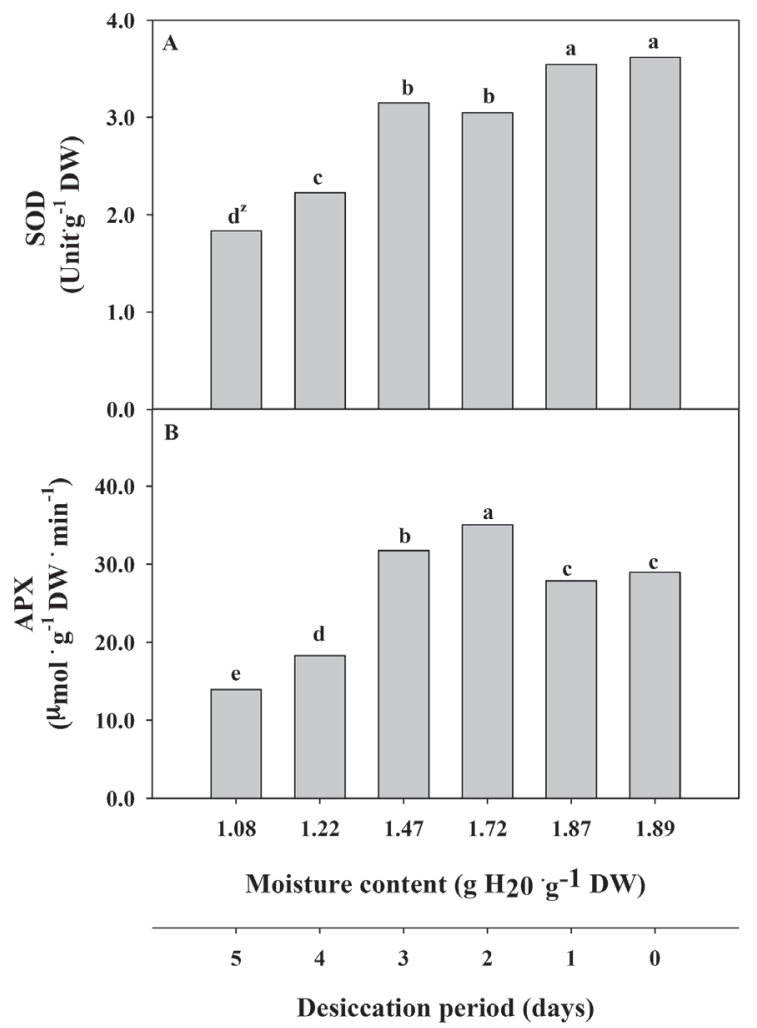

Fig. 4. Effect of seed moisture content on superoxide dismutase (SOD) and ascorbate peroxidase (APX) activity in Pachira macrocarpa.

${ }^{2}$ Means followed by the same letter within each column are not significantly different at the $5 \%$ level by LSD test

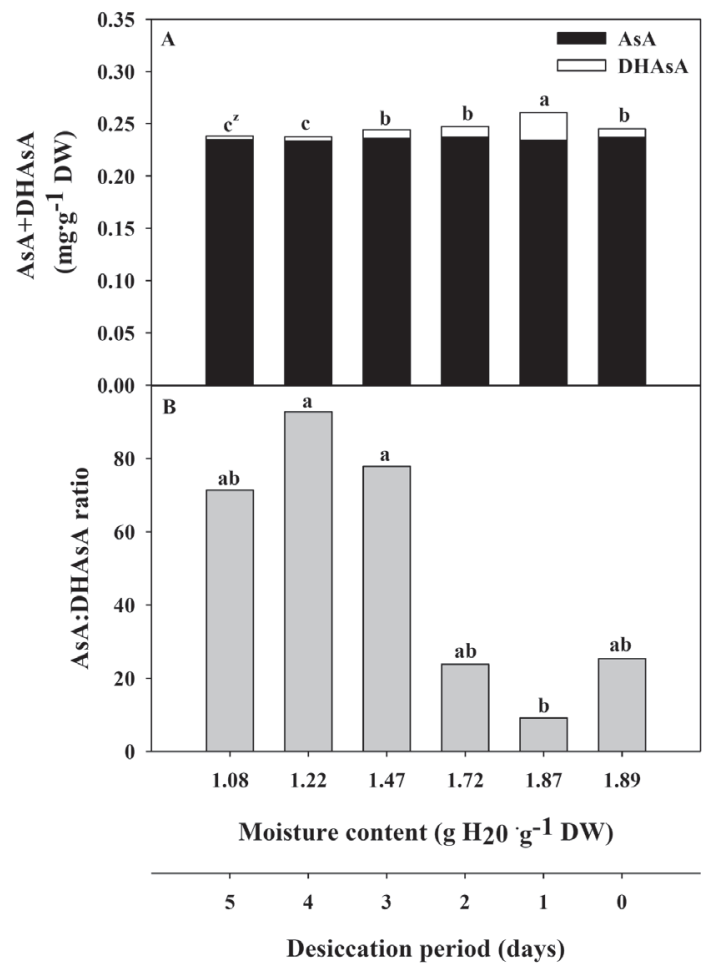

Fig. 5. Effect of seed moisture content on ascorbate (AsA) and dehydroascorbate (DHAsA) content in Pachira macrocarpa.

${ }^{2}$ Means followed by the same letter within each column are not significantly different at the $5 \%$ level by LSD test changes in DHAsA were similar to that of the total ascorbic acid quantity, which showed a significant increase during the early stages of desiccation, but subsequently declined with decreases in moisture content (Fig. 5A). By converting the AsA and DHAsA quantity into a ratio, we found that when the moisture content was higher than $1.72 \mathrm{gH}_{2} \mathrm{O} \cdot \mathrm{g}^{-1} \mathrm{DW}$, the AsA and DHAsA ratio was lower than 30. This indicates that ascorbic acid has both an oxidation state and a reduction state. Nevertheless, with a moisture content lower than $1.47 \mathrm{gH}_{2} \mathrm{O} \cdot \mathrm{g}^{-1} \mathrm{DW}$, the ratio significantly increased to above 70 , which indicates that the ascorbic acid exhibited was primarily in a reduction state (Fig. 5B). Regarding glutathione content, the total glutathione quantity increased as the moisture content decreased. When the moisture content was 1.72 and $1.08 \mathrm{gH}_{2} \mathrm{O} \cdot \mathrm{g}^{-1} \mathrm{DW}$, the glutathione content measured 0.09 and $0.22 \mathrm{mg} \cdot \mathrm{g}^{-1} \mathrm{DW}$, respectively. However, almost no GSSG existed during the desiccation period (Fig. 6A). By converting GSH and GSSG into a ratio, we found that the GSH and GSSG content increased as the moisture content decreased. Thus, as the moisture content decreases, the ratio of GSH and GSSG increases (Fig. 6B).

Finally, the MDA content in the seeds was tested for oxidation following desiccation. During desiccation, the amount of MDA increased with decreases in the moisture content. When the moisture content exceeded $1.47 \mathrm{gH}_{2} \mathrm{O} \cdot \mathrm{g}^{-1} \mathrm{DW}$, the MDA quantity was lower than $25 \mathrm{nmol} \cdot \mathrm{g}^{-1}$ DW. However, when continued desiccation reduced the moisture content to below 1.22 and $1.08 \mathrm{nmol} \cdot \mathrm{g}^{-1} \mathrm{DW}$, the MDA content increased to 30.1 and $36.6 \mathrm{nmol} \cdot \mathrm{g}^{-1} \mathrm{DW}$, respectively (Fig. 7).

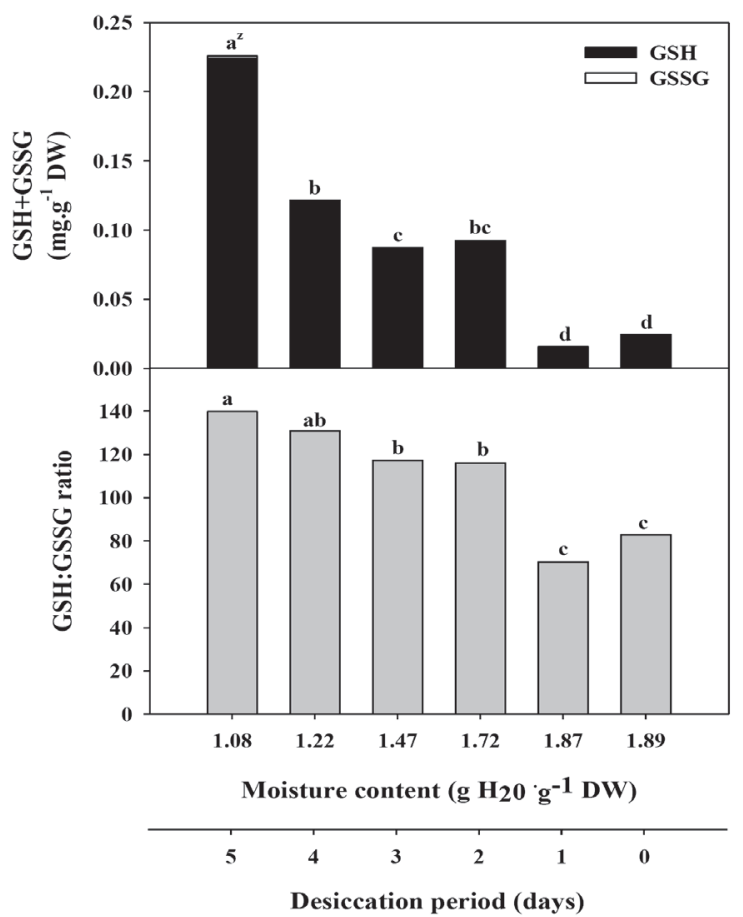

Fig. 6. Effect of seed moisture content on glutathione (GSH) and glutathione disulfide (GSSG) content in Pachira macrocarpa.

${ }^{z}$ Means followed by the same letter within each column are not significantly different at the $5 \%$ level by LSD test 


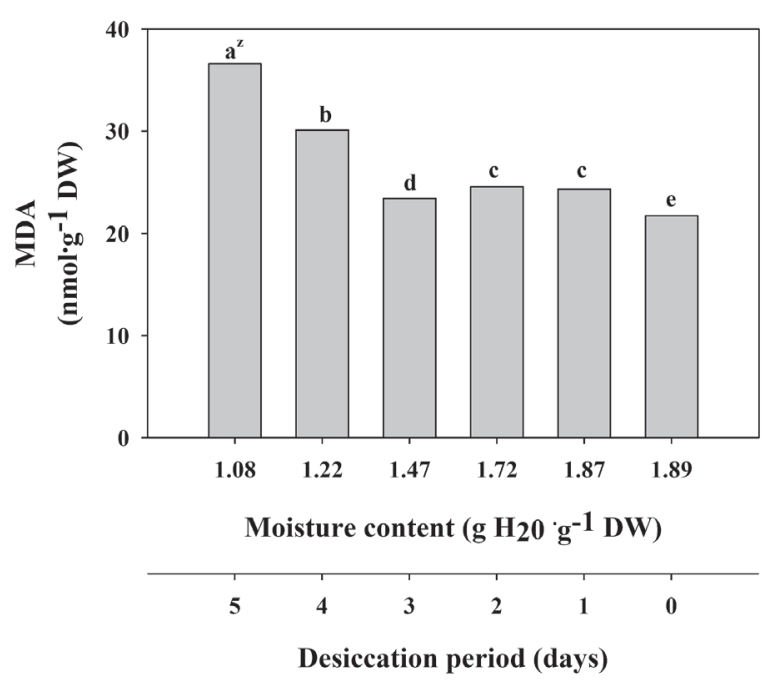

Fig. 7. Effect of seed moisture content on malondialdehyde (MDA) content in Pachira macrocarpa.

${ }^{z}$ Means followed by the same letter within each column are not significantly different at the $5 \%$ level by LSD test

\section{DISCUSSION}

The $P$. macrocarpa seeds examined in this study were desiccated at an indoor temperature of $25^{\circ} \mathrm{C}$ and a relative humidity of $60 \%$. The germination percentage declined with decreases in the seed moisture content. After 7 days of desiccation, the seed moisture content had declined to less than $1.4 \mathrm{gH}_{2} \mathrm{O} \cdot \mathrm{g}^{-1} \mathrm{DW}$, and the germination percentage was reduced to 0\% (Fig. 1B). According to many previous reports have asserted that $P$. macrocarpa seeds have a maximum storage life of 1 month, but they cannot be compared to orthodox seeds longevity (Hong et al., 1998; Sun et al., 2011). The results of this study suggest that $P$. macrocarpa seeds possess the storage characteristics of physiological intolerance to desiccation. However, Win (2008) contended that if a seed has insufficient desiccation, low temperature, or storage tolerance, it exhibits difficult to store property. Therefore, $P$. macrocarpa seeds can be categorized as recalcitrant seeds.

After T. occidentalis seeds, which are recalcitrant, were slowly desiccated for 3 days with barium chloride (85\% RH), the germination percentage declined with decreased in the seed moisture content (Ajayi et al., 2006). Similarly, after A. heterophyllus seeds were slowly desiccated using a supersaturated solution of potassium di-hydrogen phosphate $(96 \% \mathrm{RH})$ at $25^{\circ} \mathrm{C}$ for 3 days, the moisture content declined below $0.8 \mathrm{gH}_{2} \mathrm{O} \cdot \mathrm{g}^{-1}$ DW, and the germination percentage decreased drastically. When the seed moisture content of $A$. heterophyllus decreased below $0.4 \mathrm{gH}_{2} \mathrm{O} \cdot \mathrm{g}^{-1} \mathrm{DW}$, the seeds died (Wesley-Smith et al., 2001). In this study, the correlation between the moisture content of $P$. macrocarpa seeds and the germination percentage was similar to the reaction of recalcitrant seeds to desiccation. As the seed moisture content decreased, the germination percentage declined. Although the germination percentage reduction of T. occidental (Ajayi et al., 2006) seeds can be divided into three stages, $P$. macrocarpa seeds exhibited a curve reduction (Fig. 1B). This indicates that the reaction of recalcitrant seeds to desiccation differs also depending on the plant species. In addition, when $P$. macrocarpa seeds were desiccated slowly for 6 days, and the moisture content reduced to $1.4 \mathrm{gH}_{2} \mathrm{O} \cdot \mathrm{g}^{-1} \mathrm{DW}$, the seed germination percentage reached $0 \%$. This was significantly higher than the seed death moisture content of $A$. heterophyllus at $0.4 \mathrm{gH}_{2} \mathrm{O} \cdot \mathrm{g}^{-1} \mathrm{DW}$ (WesleySmith et al., 2001), which indicates that $P$. macrocarpa seeds are more sensitive to desiccation compared to recalcitrant jackfruit (A. heterophyllus) seeds. This phenomenon is similar to the argument proposed by Berjak and Pammenter (2001), that is, seed sensitivity to desiccation is not an all-or-none trait, but rather a quantitative trait, exhibiting a different distribution in desiccation sensitivity exists of recalcitrant seeds.

Furthermore, when seeds encounter desiccation, there is a substantial change in cell volume, which causes mechanical harm to the cell structure. This is especially likely to occur in the species with higher seed moisture content. In contrast, when developing orthodox seeds, reductions in vacuole volume or filling the vacuoles with insoluble substances can reduce this type of damage. While, the second type of damage is membrane structure damage. Water content is an important element of the membrane structure, and the presence of water to maintain the integrity of the membrane molecules. Once desiccated, the seed membrane structure loses water molecules, which reduces the completeness of the membrane and causes cellular dehydration damage. The final type of damage is caused by the metabolic system. Some seeds lose metabolic balance in their cells during desiccation, which generates an accumulation of free radicals inside the cells, leading to cell damage. According to previous studies report, seeds that are sensitive to desiccation have reduced metabolic activity during desiccation, which affects the seed's tolerance to desiccation (Pammenter and Berjak, 1999). After desiccating P. macrocarpa seeds in this study, a rapid reduction in seed viability was noted based on the germination percentage. In addition, observation of fresh $P$. macrocarpa seed tissue biopsies dyed with safranin showed that the cell nucleus comprised the majority of the cell volume. The cell membrane structure could be clearly observed, and obvious boarders between cells were apparent. After 9 days of desiccation, the cell membrane showed signs of rupture, the cell boarders had disappeared, and the cell nucleus began to rupture, deteriorate, and disappear. This suggested that the membrane structure had sustained damage. This finding was similar to the results of jackfruit and chinaberry seed desiccation. Jackfruit seeds that were not stored maintained a complete cell nucleus structure. The cells contained a number of large vacuoles, which comprised the majority of the cell volume. Plastids and mitochondria with suitable differentiation could be observed, indicating that cellular metabolic activity was normal (Wesley-Smith et al., 2001). Chinaberry seeds exhibited similar characteristics after desiccation. When chinaberry seeds are desiccated to a moisture content of 
$0.26 \mathrm{~g} \cdot \mathrm{g}^{-1}$, plasmolysis may occur between the plasma membrane and the cell wall, and a normal cellular structure cannot be observed (Kioko et al., 2006). After jackfruit seeds were slowly desiccated, the original large volume vacuoles observed in the cell disappeared. The soluble materials originally located in the vacuoles dissolved into the cytoplasm, increasing the osmotic potential pressure in the cell. In addition, the nuclear membranes deteriorated, generating outward expansion (WesleySmith et al., 2001). Although this study did not observe the detailed structures of the organelles in the cell's nucleus, we deduced from the cell membrane ruptures that the cell leakages were severe (Fig. 2). Comparing the seed germination percentages, the seeds were found to have already died after 9 days of desiccation. The reaction of recalcitrant seeds to desiccation was as described above.

This study discussed above verified that P. macrocarpa seeds are recalcitrant and sensitive to desiccation. After desiccation, the $\mathrm{O}_{2}^{--}$and $\mathrm{H}_{2} \mathrm{O}_{2}$ content in the seed increased with decreases in the moisture content. When the seed moisture content declined below $1.7 \mathrm{gH}_{2} \mathrm{O} \cdot \mathrm{g}^{-1} \mathrm{DW}$, the seed germination percentage was lower than $50 \%$. Although the $\mathrm{O}_{2}^{--}$content in the seed had risen slightly, the statistical deviation standard remained the same as that of fresh seeds. When the metabolic reaction was more downstream, the $\mathrm{H}_{2} \mathrm{O}_{2}$ content exhibited a clear increase, and when the moisture content declined below $1.4 \mathrm{gH}_{2} \mathrm{O} \cdot \mathrm{g}^{-1} \mathrm{DW}$, the seeds no longer possessed germination abilities (Fig. 1). The $\mathrm{O}_{2}^{--}$and $\mathrm{H}_{2} \mathrm{O}_{2}$ content in the seed at this time was 0.33 and $130.7 \mu \mathrm{g} \cdot \mathrm{g}^{-1} \mathrm{DW}$, respectively, higher than that when the moisture content was at $1.8 \mathrm{gH}_{2} \mathrm{O} \cdot \mathrm{g}^{-1} \mathrm{DW}$ (Fig. 3). When the seeds were desiccated to below $1.08 \mathrm{gH}_{2} \mathrm{O} \cdot \mathrm{g}^{-1} \mathrm{DW}$ in moisture content, the $\mathrm{H}_{2} \mathrm{O}_{2}$ quantity reached a peak of $162.3 \mu \mathrm{g} \cdot \mathrm{g}^{-1} \mathrm{DW}$ (Fig. 3). Francini et al. (2006) indicated that after A. Bidwillii seeds were desiccated, the free radical content increased with decreases in the moisture content. For seeds desiccated to $21 \%$ moisture content, the free radical content increased by a maximum of 1.8 times. Quantity changes in reactive oxygen species $\mathrm{O}_{2}^{--}$and $\mathrm{H}_{2} \mathrm{O}_{2}$ were observed in A. saccharinum L. (Pukacka and Ratajczak, 2006), C. sinensis Luntze (Chen et al., 2010), and A. toxicaria (Xin et al., 2010) seeds. The results show that as the seed moisture content decreases, the quantity of the reactive oxygen species increased. This was especially true in $C$. sinensis Luntze seeds, where when the seed moisture content declined below $20 \%$, and the $\mathrm{H}_{2} \mathrm{O}_{2}$ quantity was eight times that of a fresh seed. The results of this study indicated that the increase in reactive oxygen species after desiccation for $P$. macrocarpa seeds conformed to the findings of the above report. SOD is the first line of defense against reactive oxygen species $\mathrm{O}_{2}^{-}$; it converts $\mathrm{O}_{2}^{--}$into $\mathrm{H}_{2} \mathrm{O}_{2}$ and oxygen to reduce the toxicity of $\mathrm{O}_{2}^{--}$(Polle, 2001). In this study, after the P. macrocarpa seeds were desiccated, the SOD activity declined with decreases in the moisture content. When the seed moisture content declined below $1.8 \mathrm{gH}_{2} \mathrm{O} \cdot \mathrm{g}^{-1} \mathrm{DW}$, the SOD activity of desiccated $P$. macrocarpa seeds was significantly lower than that of the control group (Fig. 4).
A decrease in the moisture content of $T$. cacao and $P$. macrocarpa seeds also decreased the seed's SOD activity, which subsequently reduced the seed germination percentage and viability index of $P$. macrocarpa (Li and Sun, 1999; Li et al., 2009). These results indicated that desiccation of $P$. macrocarpa seeds reduces SOD activity and seed desiccation tolerance. This result can be explained; desiccation damaged the $P$. macrocarpa seeds to be the first line of defense against oxidative.

After SOD reduces $\mathrm{O}_{2}^{-}$into $\mathrm{H}_{2} \mathrm{O}_{2}$, the anti-oxidation enzyme APX reduces $\mathrm{H}_{2} \mathrm{O}_{2}$ into non-poisonous $\mathrm{H}_{2} \mathrm{O}$, and eliminates the toxicity caused by reactive oxygen species (Bailly, 2004). In this study, APX activity in P. macrocarpa seeds during the early stages of desiccation increased. However, as desiccation continued, APX activity decreased (Fig. 4B). After A. toxicaria seeds were desiccated, APX activity initially increased with decreases in the moisture content. However, as the seeds were further desiccated, APX activity began to decline (Xin et al., 2010). The change in APX activity for $A$. toxicaria seeds occurred at a moisture content of 0.2-0.4 $\mathrm{gH}_{2} \mathrm{O} \cdot \mathrm{g}^{-1}$ DW, lower than that for P. macrocarpa seeds. This change in APX activity occurred at a moisture content of below $1.72 \mathrm{gH}_{2} \mathrm{O} \cdot \mathrm{g}^{-1} \mathrm{DW}$ (Fig. 4B), significantly higher than that for A. toxicaria seeds. Thus, we infer that these two seeds possess differing sensitivities to desiccation, and that $P$. macrocarpa seeds are more sensitive to desiccation.

AsA and GSH are important metabolites in plants. Their main function is to maintain the ascorbate-glutathione cycle by eliminating the $\mathrm{H}_{2} \mathrm{O}_{2}$ produced by upstream SOD metabolism and to solve cell oxidation problems (Polle, 2001). Ascorbate-glutathione cycle is a cyclic reaction that requires the completion of one cycle to effectively eliminate $\mathrm{H}_{2} \mathrm{O}_{2}$. The ASA content in $P$. macrocarpa seeds does not vary significantly during desiccation. By contrast, DHAsA increased during the initial stages of desiccation, and then decreased as desiccation continued (Fig. 5). However, the quantity of GSH in the same cycle drastically increased during desiccation (Fig. 6 ). Based on the ratio of the reduction status and oxidation status, the ascorbic acid and glutathione content during the early desiccation phase possess a higher level of DHAsA and GSSG in the oxidation state (Figs. 5B and 6B). Overall, ascorbate-glutathione cycle has a specific reduction state and oxidation state ratio, which indicates that this cycle can be successfully conducted during the early stages of desiccation. However, when the moisture content declined, the ratio between the two shifted toward a reduction state, indicating that the cycle had stopped. During the desiccation of $Q$. robur, C. sativa, and $A$. saccharinum seeds, the GSH quantity in the seed decreased with the moisture content, whereas the GSSG quantity increased. Examining the oxidation $\mathrm{E}_{\mathrm{GSSG} / 2 \mathrm{GSH}}$ value, the $C$. sativa seed showed increasingly severe oxidation after desiccation. This result indicates that the reactive oxygen species produced in the seed could no longer be metabolized by the ascorbate-glutathione cycle, leading to cell oxidation problems (Kranner et al., 2006; Roach et al., 2010; Pukacka and Ratajczak, 2006). This 
result contrasts with that observed when $P$. macrocarpa seeds were desiccated; the ascorbate-glutathione cycle was in a reduction state. The main reason was that the SOD and APX in the upstream reaction of the P. macrocarpa anti-oxidation system had already lost activity during the desiccation process (Fig. 4). Consequently, the downstream GSH level increased and maintained a state of reduction during the desiccation process (Fig. 6 ), although normal operation of the antioxidation system could not be maintained.

Observing the actual oxidation in $P$. macrocarpa seeds after desiccation, the lipid peroxidation product MDA decreased with declines in the moisture content (Fig. 7). During the desiccation process, the thiobarbituric acid reactive substances content in A. toxicaria (Cheng and Song, 2008), A. bidwillii (Francini et al., 2006), and T. Cacao (Li and Sun, 1999) seeds all increased with decreases in the moisture content. This reaction was identical to that observed for $P$. macrocarpa seeds in this study, indicating that metabolic system-induced damage appeared after $P$. macrocarpa seeds were desiccated.

Summarizing the above results, $P$. macrocarpa seeds are recalcitrant, and the germination percentage after the seeds were desiccated exhibited a U-shaped decline, conforming to the desiccation intolerance of recalcitrant seeds. During the desiccation period, the cell membrane system structure in $P$. macrocarpa seeds ruptured, producing physical structure damage. Simultaneously, the reactive oxygen species increased, as demonstrated by the reduced upstream SOD and APX activity in the antioxidation system. This produced peroxides in the seed, leading to metabolism induced damages. These results indicated that desiccation of $P$. macrocarpa seeds produced at least two causes that reduced viability. Li et al. (2009) asserted that after P. macrocarpa seeds were desiccated, SOD activity rapidly declined. This decline caused an inability to eliminate $\mathrm{O}_{2}^{-}$, leading to severe oxidation, reduced seed viability, and seed aging and death. However, investigations of why recalcitrant $P$. macrocarpa seeds are desiccation intolerant and die during desiccation cannot verify that $P$. macrocarpa seeds died because of abnormal metabolic activity. The main reason is that abnormalities in the antioxidation system of $P$. macrocarpa seeds primarily occurred when the moisture content was below $1.22 \mathrm{gH}_{2} \mathrm{O} \cdot \mathrm{g}^{-1} \mathrm{DW}$. At this point, the amount of SOD and APX activity was significant less than that of fresh seeds (Fig. 4). However, the moisture content threshold for seed death was $1.4 \mathrm{gH}_{2} \mathrm{O} \cdot \mathrm{g}^{-1} \mathrm{DW}$ (Fig. 1). The seed's antioxidation system did not show a significant imbalance at this time, indicating that seed death occurred before the appearance of oxidation. Xin et al. (2011) focused on the relationship between seed viability and oxidation in A. toxicaria seeds after desiccation. Although Xin et al. indicated that desiccation affects seed leakage and viability, and also accompanied by an increases in seed oxidation. However, this level of oxidation is not sufficient to cause seed death. Avicennia marina seeds exhibited the greatest decline in viability when the seeds were desiccated to a moisture content of
54\% to 57\% (Greggains et al., 2001). However, lipid peroxidation at this time actually decreased. Thus, the loss of seed viability at high moisture content may be the result of mechanical or physiological damage caused by a drastic reduction in cell volume, not metabolic damage. The reduction in viability of $P$. macrocarpa seeds following desiccation was the same, and primarily accompanied by an increase in reactive oxygen species and an imbalance in the anti-oxidation system. However, the main factors influencing seed intolerance to desiccation and the reasons seeds cannot be stored for as long as orthodox seeds still require further experiments for clarification.

\section{ACKNOWLEDGEMENTS}

This study was supported by a grant from the Agriculture and Food Agency, Council of Agriculture, Executive Yuan, Taiwan, ROC. 99AS-4.2.2-FD-Z3 and 100AS-4.2.2-FD-Z3. We are also grateful to Mr. Wu-Chou Chung and Mr. Chi-Hua Lin for providing the seeds materials and to Miss Ying-Jhen Chen for help investigating.

\section{REFERENCES}

Ajayi, S. A., P. Berjak, J. I. Kioko, M. E. Dulloo, R. S. Vodouhe 2006 Responses of fluted pumpkin (Telfairia occidentalis Hook. f., Cucurbitaceae) seeds to desiccation, chilling and hydrated storage. S. Afr. J. Bot., 72: 544-550

Bailly, C. 2004 Active oxygen species and antioxidants in seed biology. Seed Sci. Res., 14: 93-107

Berjak, P. and N. W. Pammenter. 2001 Seed recalcitrance : current perspectives. S. Afr. J. Bot., 67: 79-89

Bonner, F. T. 1996 Responses to drying of recalcitrant seeds of Quercus nigra L. Ann. Bot., 78: 181-187

Chen, Q., L. Yang, P. Ahmad, X. Wan, X. Hu. 2010 Proteomic profiling and redox status alteration of recalcitrant tea (Camellia sinensis) seed in response to desiccation. Planta, 233: 583592

Cheng, H. Y. and S. Q. Song. 2008 Possible involvement of reactive oxygen species scavenging enzymes in desiccation sensitivity of Antiaris toxicaria seeds and axes. J. Integr. Plant Biol., 50: 1549-1556

Ellis, R. H., T. D. Hong, and E. H. Roberts. 1991 An intermediate category of seed storage behaviour? II. Effects of provenance, immaturity, and imbibition on desiccation-tolerance in coffee. J. Exp. Bot. 42: 653-657

Farrant, J. M., N. W. Pammenter, P. Berjak. 1988 Recalcitrance- a current assessment. Seed Sci. Tech., 16: 155-166

Francini, A., L. Galleschi, F. Saviozzi, C. Pinzino, R. Izzo, C. Sgherric, F. Navari-Izzo. 2006 Enzymatic and non-enzymatic protective mechanisms in recalcitrant seeds of Araucaria bidwillii subjected to desiccation. Plant Physiol. Biochem., 44: 556-563

Greggains, V, W. E. Finch-Savage, N. M. Atherton, P. Berjak. 2001 Viability loss and free radical processes during desiccation of recalcitrant Avicennia marina seeds. Seed Sci. Res., 11: 235-242

Heath, R. L. and L. Paker. 1968 Photoperoxidation in isolated chloroplasts. I. Kinetics and stoichiometry to fatty acid peroxidation. Arch. Biochem. Biophy., 125: 189-198

Hong, T. D. and R. H. Ellis. 1996 A Protocol to determine seed storage behavior. IPGRI Technical Bulletin No. 1. IPGRI., Rome

Hong, T. D., S. Linington, R. H. Ellis. 1996 Seed storage behavior : a compendium. Handbooks for Genebanks : No. 4. IPGRI. 
Rome

Hong, T. D., S. Linington, R. H. Ellis. 1998 Compendium of information on seed storage behavior, Vol. 1 and 2. Royal Botanic Garden, Kew, UK

Kioko, J. I., P. Berjak, N. W. Pammenter. 2006 Viability and ultrastructural responses of seeds and embryonic axes of Trichilia emetica to different dehydration and storage conditions. S. Afr. J. Bot., 72: 167-176

Kranner, I., S. Birtić, K. M. Anderson, H. W. Pritchard. 2006 Glutathione half-cell reduction potential: a universal stress marker and modulator of programmed cell death? Free Radic. Biol. Med., 40: 2155-2156

Law, M. Y., S. A. Charles, B. Halliwell. 1983 Glutathione and ascorbic acid in spinach (Spinacia oleracea) chloroplaststhe effect of hydrogen peroxide and of paraquat. Biochem. J., 210: 899-903

Li, C. and W. Q. Sun. 1999 Desiccation sensitivity and activities of free radical scavenging enzymes in recalcitrant Theobroma cacao seeds. Seed Sci. Res., 9: 209-217

Li, Y. H., Y. M. Ma, L. Han. 2009 Relationship between tolerance to dehydration and superoxide dismutases (SODs) in Pachira marcrocarpa. Scientia Silvae Sinica, 45: 74-79

Liu, J., J. Zhou, D. Xing. 2012 Phosphatidylinositol 3-kinase plays a vital role in regulation of rice seed vigor via altering NADPH oxidase activity. Plos One, 7: 1-11

Nakano, Y. and K. Asada. 1981 Hydrogen peroxide is scavenged by ascorbate specific peroxidase in spinach chloroplasts. Plant Cell Physiol., 22: 867-880

Pammenter, N. W. and P. Berjak. 1999 A review of recalcitrant seed physiology in relation to desiccation-tolerance mechanisms. Seed Sci. Res. 9: 13-37

Paoletti, F., D. Aldinucci, A. Mocali, and A. Capparini. 1986 A sensitive spectrophotometric method for the determination of superoxide dismutase activity in tissue extracts. Anal. Biochem., 154: 536-541

Polle, A. 2001 Dissecting the superoxide dismutase-ascorbate- glutathione-pathway in chloroplasts by metabolic modeling. Plant Physiol., 126: 445-462

Pukacka, S. and E. Ratajczak. 2006 Antioxidative response of ascorbate-glutathione pathway enzymes and metabolites to desiccation of recalcitrant Acer saccharinum seeds. J. Plant Physiol., 163: 1259-1266

Roach, T., R .P. Beckett, F. V. Minibayeva, L. Colville, C. Whitaker H. Chen, C. Bailly, I. Kranner. 2010 Extracellular superoxide production, viability and redox poise in response to desiccation in recalcitrant Castanea sativa seeds. Plant Cell Environ. 33: 59-75

Roberts, E. H. 1973 Predicting the storage life of seeds. Seed Sci. Tech., 1: 499-514

Sagisaka, S. 1976 he occurrence of peroxide in perennial plant, Populus gelrica. Plant Physiol., 57: 308-309

Smith, I. K. 1985 Stimulation of glutathione synthesis in photo respiring plants by catalase inhibitors. Plant Physiol., 79 1044-1047

Sun, Y. W., S. T. Kuo, M. T. Liu, W. W. Liao, W. C. Chung. 2011 The storage and mutagenic technique in Pachira macrocarpa. Seed Sci. Tech., 74: 14-16

Tang, A. J. and C. L. Long. 2008 Seed germination of Lasia spinosa as a function of temperature, light, desiccation, and storage. Aquat. Bot., 89: 352-365

Tsai, S. H. 1975 A scheme of plant tissue section technology. Mau-Chang Co. Taipei, Taiwan.

Wesley-Smith, J., N. W. Pammenter, P. Berjak, C. Walters. 2001 The effects of two drying rates on the desiccation tolerance of embryonic axes of recalcitrant jackfruit (Artocarpus heterophyllus Lamk.) seeds. Ann. Bot., 88: 653-664

Win, B. 2008 On the compound quantitative characteristic trait of seed recalcitrant. Acta Bot. Yunnanica, 30: 76-88

Xin, X., X. M. Jing, Y. Liu, and S. Q. Song 2010 Viability loss pattern under rapid dehydration of Antiaris toxicaria axes and its relation to oxidative damage. J. Integr. Plant Bio. 52 $434-441$ 